\title{
Molecular cytogenetic characterization of wheat-Elymus repens chromosomal translocation lines with resistance to Fusarium head blight and stripe rust
}

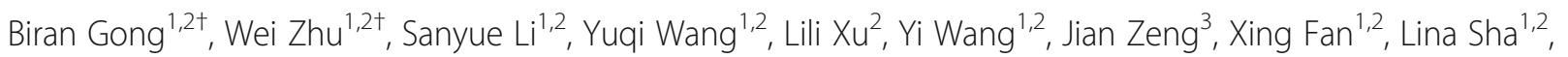
Haiqin Zhang ${ }^{1,2}$, Pengfei Qi ${ }^{1,2}$, Lin Huang ${ }^{1,2}$, Guoyue Chen ${ }^{1,2}$, Yonghong Zhou ${ }^{1,2}$ and Houyang Kang ${ }^{1,2^{*}}$

\begin{abstract}
Background: Fusarium head blight (FHB) caused by the fungus Fusarium graminearum Schwabe and stripe rust caused by Puccinia striiformis f. sp. tritici are devastating diseases that affect wheat production worldwide. The use of disease-resistant genes and cultivars is the most effective means of reducing fungicide applications to combat these diseases. Elymus repens $(2 n=6 x=42, \mathrm{StStStStHH})$ is a potentially useful germplasm of FHB and stripe rust resistance for wheat improvement.

Results: Here, we report the development and characterization of two wheat-E. repens lines derived from the progeny of common wheat-E. repens hybrids. Cytological studies indicated that the mean chromosome configuration of K15-1192-2 and K15-1194-2 at meiosis were $2 n=42=0.86 I+17.46 ~||(r i n g)+3.11 ~ \| I(r o d)$ and $2 n=42=2.45 I+14.17 \|$ (ring) $+5.50 \mathrm{II}(\mathrm{rod})+0.07 \mathrm{II}$, respectively. Genomic and fluorescence in situ hybridization karyotyping and simple sequence repeats markers revealed that K15-1192-2 was a wheat-E. repens 3D/?St double terminal chromosomal translocation line. Line K15-1194-2 was identified as harboring a pair of 7DS/?StL Robertsonian translocations and one 3D/?St double terminal translocational chromosome. Further analyses using specific expressed sequence tag-SSR markers confirmed that the wheatE. repens translocations involved the 3 St chromatin in both lines. Furthermore, compared with the wheat parent Chuannong16, K15-1192-2 and K15-1194-2 expressed high levels of resistance to FHB and stripe rust pathogens prevalent in China.

Conclusions: Thus, this study has determined that the chromosome 3St of E. repens harbors gene(s) highly resistant to FHB and stripe rust, and chromatin of 3St introgressed into wheat chromosomes completely presented the resistance, indicating the feasibility of using these translocation lines as novel material for breeding resistant wheat cultivars and alien gene mining.
\end{abstract}

Keywords: Chromosomal translocation line, Elymus repens, Fusarium head blight (FHB), Stripe rust

\footnotetext{
* Correspondence: houyang.kang@sicau.edu.cn

†Biran Gong and Wei Zhu contributed equally to this work.

${ }^{1}$ State Key Laboratory of Crop Gene Exploration and Utilization in Southwest

China, Sichuan Agricultural University, Chengdu 611130, Sichuan, China

${ }^{2}$ Triticeae Research Institute, Sichuan Agricultural University, Chengdu

611130, Sichuan, China

Full list of author information is available at the end of the article
}

(c) The Author(s). 2019 Open Access This article is distributed under the terms of the Creative Commons Attribution 4.0 International License (http://creativecommons.org/licenses/by/4.0/), which permits unrestricted use, distribution, and reproduction in any medium, provided you give appropriate credit to the original author(s) and the source, provide a link to the Creative Commons license, and indicate if changes were made. The Creative Commons Public Domain Dedication waiver (http://creativecommons.org/publicdomain/zero/1.0/) applies to the data made available in this article, unless otherwise stated. 


\section{Background}

Fusarium head blight (FHB), mainly caused by the ascomycete fungus Fusarium graminearum Schwabe [telomorph, Gibberella zeae (Schw.) Petch], is an important disease of wheat (Triticum aestivum L.) worldwide [1, 2]. FHB causes significant yield losses, as well as reduced grain quality and functionality, owing to Fusarium-damaged kernels and mycotoxin contamination (mainly deoxynivalenol), which threaten food and feed security [3, 4]. Breeding resistant cultivars is generally considered the most effective and environmentally friendly strategy to control FHB [5]. To date, more than 100 unique quantitative trait loci (QTLs) have been reported on the 21 chromosomes of 50 wheat sources of resistant cultivars [6, 7]. Additionally, only a few formally designated FHB-resistance genes originated from the wild relatives of wheat, such as Fhb3 derived from Leymus racemosus, Fhb6 derived from Elymus tsukushiensis, and Fhb7 derived from Thinopyrum ponticum [8-10]. Therefore, the discovery, development, and characterization of more new resistance sources will provide breeders with a wider choice of germplasm $[7,10]$.

Stripe rust, caused by Puccinia striiformis Westend. f. sp. tritici Eriks. (Pst), is a devastating disease to wheat production in many regions of the world [11]. New disease-resistant genes and cultivars are the most effective means of reducing the amounts of fungicides applied to combat this disease [12]. At present, 81 formally designated and 67 provisionally designated stripe rust resistance $(Y r)$ genes and more than 330 QTLs are known to be distributed in common wheat and its relatives [13, 14]. However, most of the resistance genes (such as Yr1-4, Yr6-10, Yr17, Yr20-22, Yr24-29, and Yr43) are ineffective against the newly emerged virulent stripe rust race V26/Gui22 and its variants $[15,16]$. Wild relatives of common wheat contain a large number of genes conferring desirable traits that can be exploited for wheat improvement [17]. For example, 23 formally designated genes are derived from wild wheat-related species in the tertiary gene pool, including Secale cereale, Dasypyrum villosum, Thinopyrum intermedium, Th. ponticum, and several Aegilops species [13, 18]. Hence, the identification of new resistance sources in adapted germplasm is an important and long-term objective in achieving durable and broad-spectrum resistance.

As an important wild relative of wheat, Elymus repens (L.) Gould [syn. Agropyron repens (L.) P. Beauvoir, Elytrigia repens (L.) Deskv. Ex. Nevski, and Triticum repens L.] possesses the StStStStHH genome and is distributed widely throughout the world [19]. It is a valuable species for wheat improvement because it tolerates a variety of soil types, heavy metals, and cold stress [20]. To date, there are few reports regarding its disease resistance. Zeng et al. [21] developed eight wheat $-E$. repens introgression lines with chromosomal numbers ranging from 42 to 56 . These lines are resistant to FHB compared with the control cultivars $T$. aestivum "Roblin" and "Crocus". It was concluded that these lines carry the FHB-resistance gene from $E$. repens. To transfer desirable traits from $E$. repens into wheat cultivars of the Sichuan Basin, China, we produced many progeny lines by crossing and backcrossing the wheat $-E$. repens line P1142-1-2 $(2 n=56)$ with the native wheat cultivars. The present study was undertaken to develop and characterize wheat $-E$. repens translocation lines using genomic in situ hybridization (GISH), fluorescence in situ hybridization (FISH), and molecular markers. Additionally, their effects on FHB and stripe rust resistance and agronomical traits were evaluated.

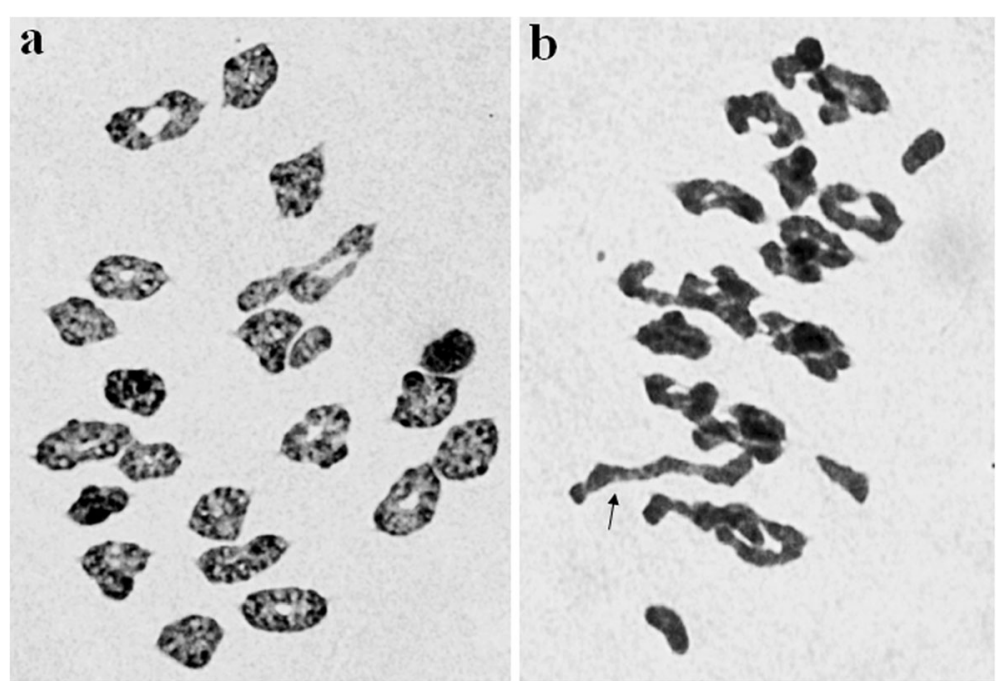

Fig. 1 Meiotic metaphase I pairing analysis of K15-1192-2 (a) and K15-1194-2 (b). a, $2 n=42=2$ I + 20 || (ring); b, $2 n=42=3$ I + $16 \|$ (ring) +2 || $($ rod) $+1 \mathrm{III}$. The arrow indicate the trivalent 


\section{Results}

Meiotic behavior of the derivative lines

Chromosomal pairing at meiotic metaphase I in PMCs of K15-1192-2 was high, with an average chromosomal configuration of 0.86 univalents +17.46 ring bivalents + 3.11 rod bivalents scored in $\sim 50$ PMCs per plant (Fig. 1a). Line K15-1194-2 had an average meiotic configuration of $2 n=42=2.45 \mathrm{I}+14.17$ II (ring) +5.50 II (rod) + 0.07 III per PMC (Fig. 1b). No lagging chromosomes or bridges were observed at anaphase I and II.

\section{GISH and FISH analyses}

P1142-1-2 simultaneously probed with Pse. strigosa (St genome) and $H$. bogdanii (H genome) DNA showing the complete 42 chromosomes of wheat, two St-genome chromosomes, four chromosomes with wheat, $\mathrm{H}$, and $\mathrm{St}$ genome large fragments, plus eight wheat chromosomes with double St-genome terminal translocations (Fig. 2). When $E$. repens total genomic DNA was used as the probe and J-11 genomic DNA as the block, we observed 40 wheat chromosomes plus two wheat-E. repens double terminal translocational chromosomes in K151192-2 (Fig. 3a). K15-1194-2 $(2 n=42)$ was found to have a pair of wheat $-E$. repens Robertsonian translocations and one double terminal translocational chromosome (Fig. 3b). To further determine the identities of the alien chromosomes involved in the translocations, GISH was also performed using the total genomic DNA of $H$.

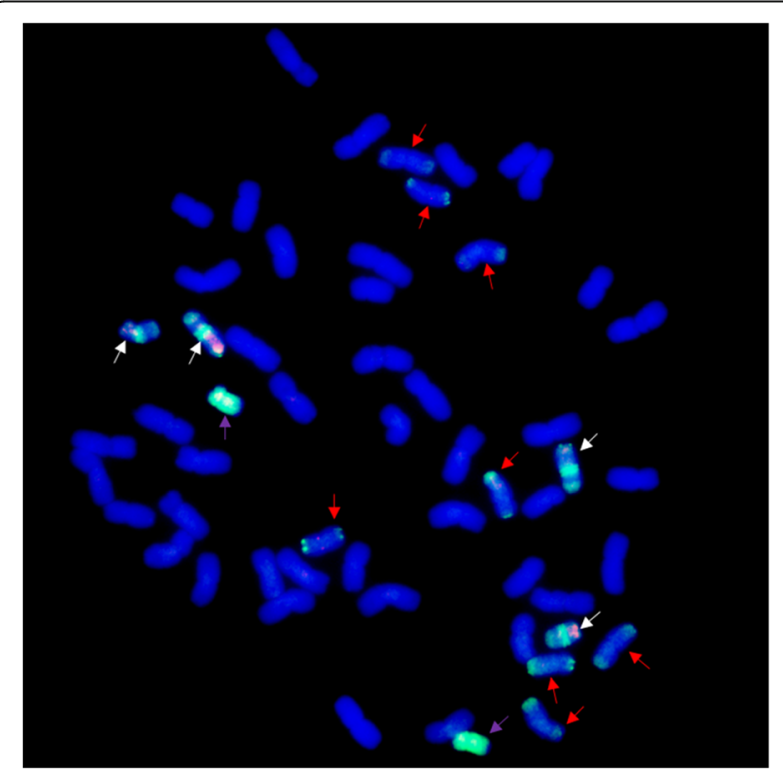

Fig. 2 The genomic constitution of P1142-1-2 as revealed by multicolor GISH analysis. The probes used for in situ hybridization were Pse. strigosa DNA (green) and H. bogdanii DNA (red), which containing two St-genome chromosomes (purple arrows), four chromosomes with wheat, $\mathrm{H}$, and St genome large fragments (white arrows), plus eight wheat chromosomes with double St-genome terminal translocations (red arrows)

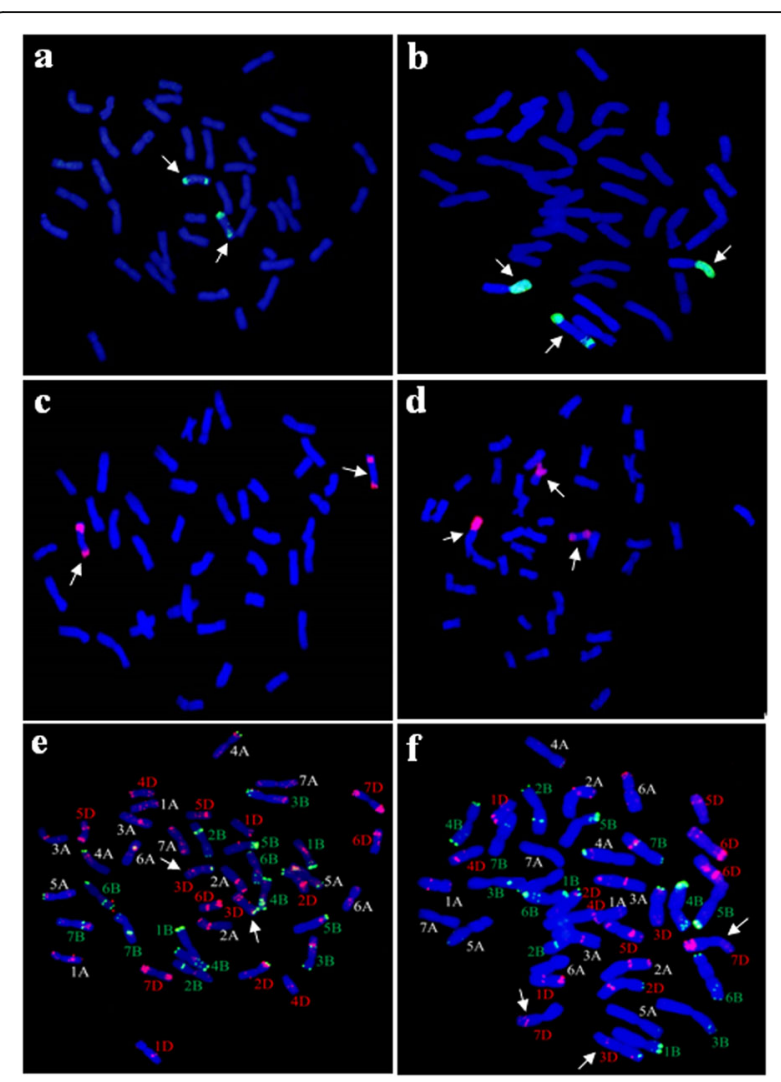

Fig. 3 GISH (a-d) and FISH (e-f) identification of K15-1192-2 (a, c, e) and K15-1194-2 (b, d, f). The probes used for in situ hybridization were E. repens genomic DNA (a, b); Pse. strigosa genomic DNA (c, d); pSc119.2 and pTa535 (e, f). Arrows indicate the wheat-E.repens translocational chromosomes

bogdanii and Pse. strigosa as the probe. However, $H$. bogdanii chromatin was not detected in the two lines. Thus, the wheat $-E$. repens translocations involved the St genome by virtue of the signals appearing on the translocated chromosomes of the two lines (Fig. 3c, d).

To further determine the identity of the wheat chromosomes involved in the translocations, FISH was performed on the translocation using pSc119.2 and pTa535 probes. We revealed that the double terminal translocated fragment of line K15-1192-2 was situated on wheat chromosome 3DS and 3DL (Fig. 3e). Line K151194-2 was identified as harboring a pair of 7DS/?StL Robertsonian translocations and one 3D/?St double terminal translocational chromosome (Fig. 3f).

\section{Molecular marker analyses}

The amplification products for the terminal regions of wheat chromosomes 3DS-and 3DL-SSR specific markers (i.e., Xcfd64 and Xcfd211) were observed in K15-1194-2, P1142-1-2, CS, and CN16. In contrast, no amplicons were generated for K15-1192-2 by these two primers (Fig. 4a, b). The SSR analysis also indicated that 

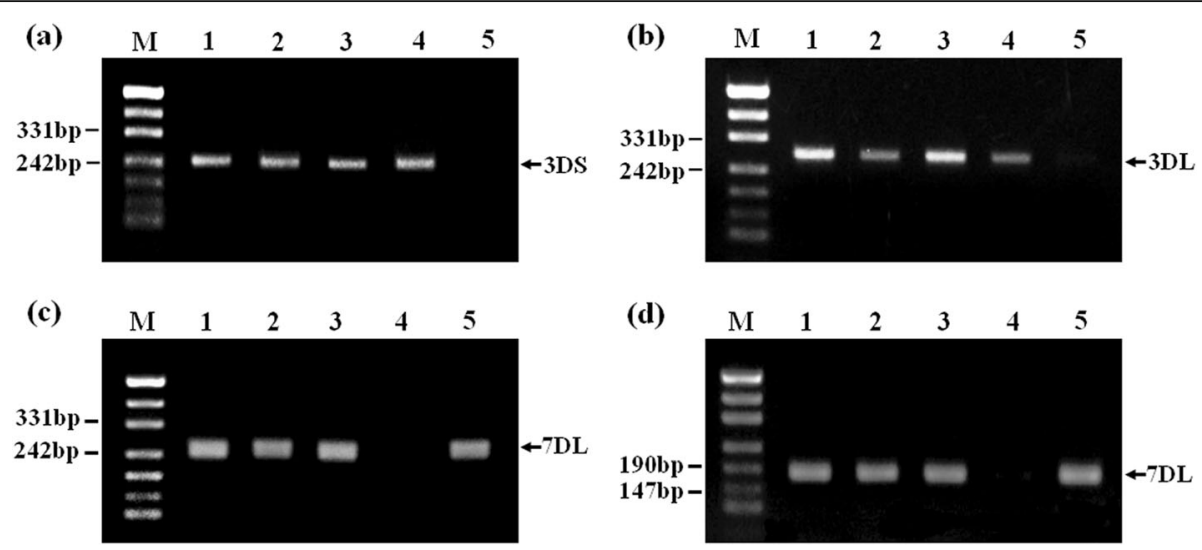

Fig. 4 Amplification patterns of wheat SSR markers. a, Chromosome 3DS SSR marker Xcfd64; b. Chromosome 3DL SSR marker Xcfd211; c, Chromosome 7DL SSR marker XWmC14; d, Chromosome 7DL SSR marker Xbarc111. Arrows indicate the amplification products diagnostic for wheat D -genome chromosomes. M, DNA ladder; 1, CS; 2, CN16; 3, P1142-1-2; 4, K15-1194-2; 5, K15-1192-2

amplification with two primer pairs (Xwmc14 and Xbarc111), which were specific for chromosome 7DL, yielded bands of the expected size from K15-1192-2, P1142-1-2, CS, and CN16 but not from K15-1194-2 (Fig. 4c, d).

Kong et al. [22] developed the molecular markers specific to $1 \mathrm{St}-7 \mathrm{St}$ chromosome of Roegneria ciliaris according to ESTs of wheat. Using these EST-SSR markers, we showed that the marker 3EST-147 specific for 3St chromosome (ID of ESTs: BF293133) amplified common band (760 bp) in $E$. repens, P1142-1-2, K15-1192-2, and K15-1194-2, but this band was not amplified in CS and CN16 (Fig. 5a). In contrast, the specific bands amplified by the EST-SSR markers specific for chromosome $1 \mathrm{St}, 2 \mathrm{St}$, $4 \mathrm{St}, 5 \mathrm{St}, 6 \mathrm{St}$, and $7 \mathrm{St}$ were not detected between E. repens or P1142-1-2 and K15-11922, K15-1194-2 (Fig. 5b). Those results confirmed that the alien chromatin involved in both translocations was derived from 3St chromosome of E. repens.

\section{Morphology of K15-1192-2 and K15-1194-2}

K15-1192-2 and K15-1194-2 displayed stable morphological traits between the parents CN16 and P1142-1-2 (Table 1). Their average plant height were significantly greater than those of CN16 or P1142-1-2. The tiller number of the two lines was significantly greater than that of $\mathrm{CN16}$, and similar to that of P1142-1-2. The average spike length of K15-11942 were significantly greater than that of P1142-1-2, CN16, and K15-1192-2. The thousand-kernel weight of K15-11922 and K15-1194-2 was significantly greater than that of P1142-1-2, but lower than that of CN16. No significant differences in spikelets per spike were observed among K151192-2, K15-1194-2, and either CN16 or P1142-1-2.

\section{FHB resistance evaluation}

K15-1192-2, K15-1194-2, P1142-1-2, CN16, and SY9571 were evaluated for FHB resistance in the controlled- environment room. The susceptible comparison line SY95-71 and the parents CN16 and P1142-1-2 had mean 93.3, 58.8, and 7.7\% infected florets, respectively. In contrast, K15-1194-2 and K15-1192-2 were resistant (Fig. 6), with mean infection rates of 7.1 and $8.3 \%$, respectively, similar to that of P1142-1-2.

\section{Stripe rust resistance}

At the adult plant stages, each plant of the three replications of lines CN16 and SY95-71 were susceptible to a mixture of Pst races CYR-32, CYR-33, CYR-34, and V26/Gui22-14, both showing infection types 4. In contrast, P1142-1-2, K15-1192-2, and K15-1194-2 plants were highly resistant to these races, all showing infection types 0; (Fig. 7). The stripe rust evaluation at seedling stage indicated that P1142-1-2, K15-1192-2, and K151194-2 were highly resistant to Pst race CYR-34. In contrast, SY95-71, and the parental lines CN16 and Crocus were highly susceptible (Fig. 8).

\section{Discussion}

Most translocational genotypes between wheat and wild related species from genera Aegilops, Secale, Hordeum, Thinopyrum, Agropyron, Dasypyrum, Leymus, and Psathyrostachys have been successfully produced in current wheat breeding programme [23-25]. Elymus L. sensu lato species possess resistance or tolerance to various biotic and abiotic stresses, and it serves as an important wild gene pool that can increase the genetic diversity of common wheat $[26,27]$. The production of wheat-Elymus compensating translocations with targeted alien chromosomes is the first important step for transferring genes from Elymus species to wheat for breeding purposes. To date, some introgressions from Elymus species into wheat have been produced, including E. trachaycaulus, E. ciliaris, and E. 

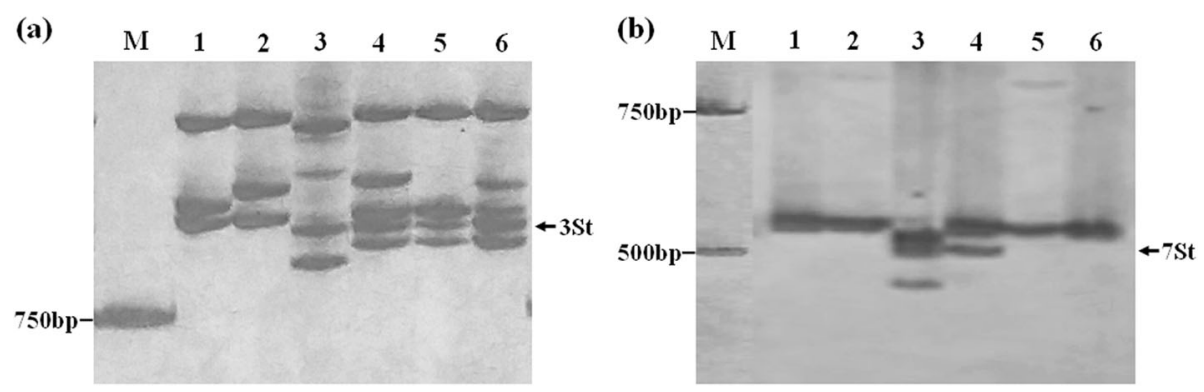

Fig. 5 Amplification patterns of EST-SSR markers 3EST-147 (a) and 7EST-133(b). Arrows indicate the amplification products diagnostic for E. repens St-genome chromosomes. M, DNA ladder; 1, CS; 2, CN16; 3, E. repens; 4, P1142-1-2; 5, K15-1194-2; 6, K15-1192-2

tsukushiense [9, 26-28]. Wide crosses between E. repens and common wheat began in the 1980s [29]. Zeng et al. [21] developed and characterized eight common wheat $-E$. repens $\mathrm{BC}_{1} \mathrm{~F}_{9}$ progeny lines, and numerous translocational chromosomes were detected in these lines. Among these lines, P1142-1-2 $(2 n=56)$ contains 42 wheat chromosomes and 14 translocational chromosomes invovling the W-St-H and St-H translocations, which is regarded as significant breeding potential material [21]. We confimed that P11421-2 consisted of the complete 42 chromosomes of wheat, two St-genome chromosomes, four chromosomes with wheat, $\mathrm{H}$, and St genome large fragments, plus eight wheat chromosomes with double Stgenome terminal translocations. To transfer desirable traits from $E$. repens into wheat cultivars of the Sichuan Basin, China, we crossed P1142-1-2 with CN16, and the $F_{1}$ was backcrossed with CN16. The homozygous translocation lines K15-1192-2 and K15-1194-2 were identified from the P1142-1-2/ $2 * \mathrm{CN} 16 \mathrm{BC}_{1} \mathrm{~F}_{3}$ progeny lines. GISH and FISH analyses of somatic metaphase chromosomes confirmed the presence of a wheat $-E$. repens $3 \mathrm{D} /$ ? St double terminal translocation and 7DS/?StL Robertsonian translocation, respectively. Fedak et al. [30] indicated that P1142-3-15 also had 42 chromosomes with one pair of chromosomes showing terminal translocations on both 3D arms. However, it was obtained from the common wheat Crocus/E. repens//Crocus $\mathrm{F}_{9}$ progeny lines. Furthermore, The line K15-1192-2 had an average of 20.57 bivalents and 0.86 univalents, but the lower incidence of univalents (0.34) were observed in line P1142-3-15 [21]. The FHB resistance of K151192-2 had infection rates of $8.3 \%$ compared with P1142-3-15 at $11.46 \%$ [21]. Therefore, K15-1192-2 and P1142-3-15 are the different translocation lines though they have the terminal translocations on both $3 \mathrm{D}$ arms. We further confirmed that the wheat $-E$. repens translocations in K15-1192-2 and K15-1194-2 involved the 3St chromatin using St-specific EST-SSR markers, which was consistent with the amplification results of Kong et al. [22]. These results, together with the high cytological stability of the two lines, indicated that the chromatin that was transferred from 3 St of E. repens compensated for the lack of wheat chromatin. These lines provide appropriate bridgebreeding-materials for alien gene introgression to improve wheat disease resistance.

Resistance to FHB has been a major focus of wheat breeding efforts for many decades and has relied on diverse germplasm resources [31]. Sources of FHB resistance used in current wheat breeding programs can be traced to limited parents, including Sumai 3 and its derivatives, Wangshuibai and Wuhan 1 [6]. Therefore, there is a constant need for evaluating and identifying new sources of resistance in alien germplasm as well as in wheat [9]. Liu et al. [32] indicated that Roegneria ciliaris, Roegneria kamoji, and $L$. racemosus had high levels of resistance to FHB. Fu et al. [33] found a FHB resistance gene located on chromosome $7 \mathrm{E}$ that was derived from Th. elongatum, but it was not used owing to linkage drag. Fhb3 was derived from a tetraploid wheat

Table 1 Agronomic traits of K15-1192-2 and K15-1194-2 and their parental lines

\begin{tabular}{|c|c|c|c|c|c|c|c|}
\hline Lines & Plant height $(\mathrm{cm})$ & Tiller number & Spike length (cm) & Spikelet per spike & Grains per spike & Seed setting rate (\%) & Thousand-grain weight \\
\hline P1142-1-2 & $89.7 \pm 2.7 b$ & $12.3 \pm 1.3 a$ & $9.7 \pm 1.0 b$ & $22.5 \pm 2.0 a$ & $27.7 \pm 1.5 b$ & $61.6 \pm 13.4 c$ & $19.4 \pm 0.4 d$ \\
\hline CN16 & $75.2 \pm 1.3 c$ & $9.4 \pm 1.1 b$ & $11.3 \pm 1.0 \mathrm{ab}$ & $20.3 \pm 1.2 \mathrm{a}$ & $38.3 \pm 3.5 a$ & $94.3 \pm 3.6 a$ & $41.0 \pm 0.5 a$ \\
\hline K15-1192-2 & $96.1 \pm 3.8 \mathrm{a}$ & $11.9 \pm 0.9 a$ & $10.1 \pm 1.5 b$ & $19.6 \pm 1.7 \mathrm{a}$ & $27.8 \pm 6.4 b$ & $70.9 \pm 4.7 b$ & $28.5 \pm 1.7 c$ \\
\hline K15-1194-2 & $100.5 \pm 4.6 \mathrm{a}$ & $12.5 \pm 2.2 \mathrm{a}$ & $12.2 \pm 1.4 a$ & $22.3 \pm 2.0 a$ & $24.5 \pm 8.6 b$ & $54.9 \pm 6.2 d$ & $34.3 \pm 0.9 b$ \\
\hline
\end{tabular}

Data in the columns indicate means \pm standard errors

Lowercase letters following the means indicate significant differences at $P<0.05$ as determined by the least significant differences 


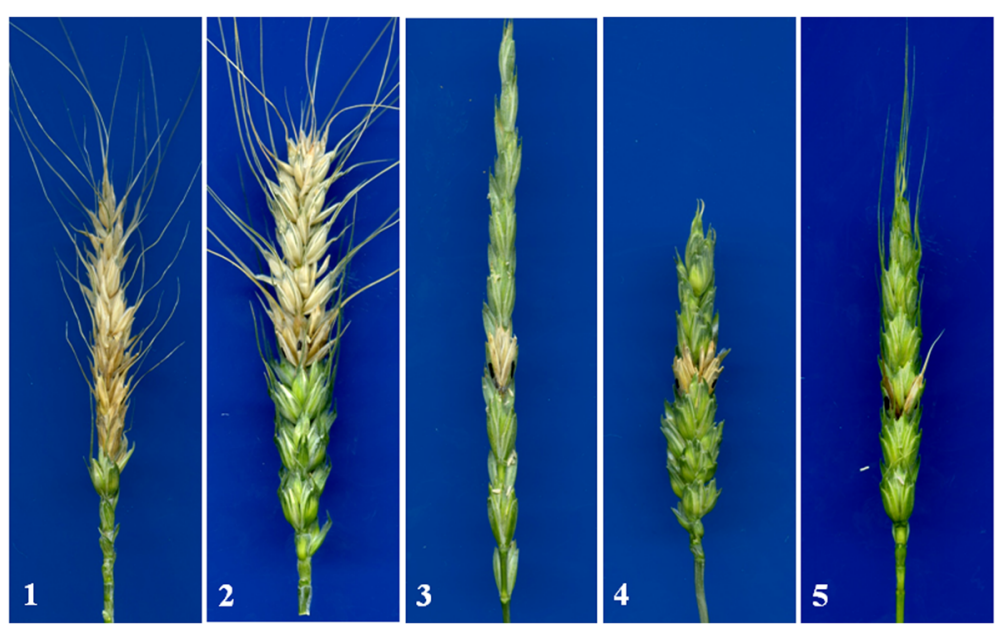

Fig. 6 Symptoms on K15-1192-2, K15-1194-2, and the controls at 21 days after inoculation with Fusarium graminearum spores. 1, SY95-71; 2, CN16; 3, P1142-1-2; 4, K15-1194-2; 5, K15-1192-2

relative, $L$. racemosus, and was transferred to wheat in the form of a compensating Robertsonian translocation T7AL.7Lr\#1S [8]. Cainong et al. [9] successfully mapped and transferred the Fhb6 from E. tsukushiensis into wheat. Guo et al. [10] developed and characterized secondary 7DS.7el ${ }_{2} \mathrm{~L}$ translocation lines with shortened Th. ponticum segments carrying Fhb7. FHB resistance has also been documented in Aegilops tauschii, E. trachaycaulus, E. repens, $R$. ciliaris, Th. junceum, Triticum monococcum, Triticum timopheevii, Triticum carthlicum, and Triticum macha [22, 27, 30, 31, 34]. Recently, Fedak et al. [30] revealed that FHB resistance was provided by the wheat $-E$. repens translocation on the long arm of chromosome 3D. Zeng et al. [21] reported that eight wheat $-E$. repens introgression lines expressed high levels of resistance to FHB, and line P1142-1-2 $(2 n=56)$ displayed an $11.35 \%$ infection rate. At present, most wheat cultivars and breeding lines from the Sichuan Basin, China are susceptible to FHB. To provide novel FHB resistance resources and transfer new genes to wheat cultivars grown in Sichuan, we developed and characterized two new wheat $-E$. repens homozygous translocation lines $(2 n=42)$ from P1142-1-2/2*CN16 generation. Compared with the infection rate of the parent $\mathrm{CN} 16$ (58.8\%), K15-1192-2 (8.3\%) and K15-1194-2 (7.1\%) were highly resistant to FHB. Therefore, the new translocation lines may represent valuable germplasm for breeding FHB-resistant wheat cultivars.

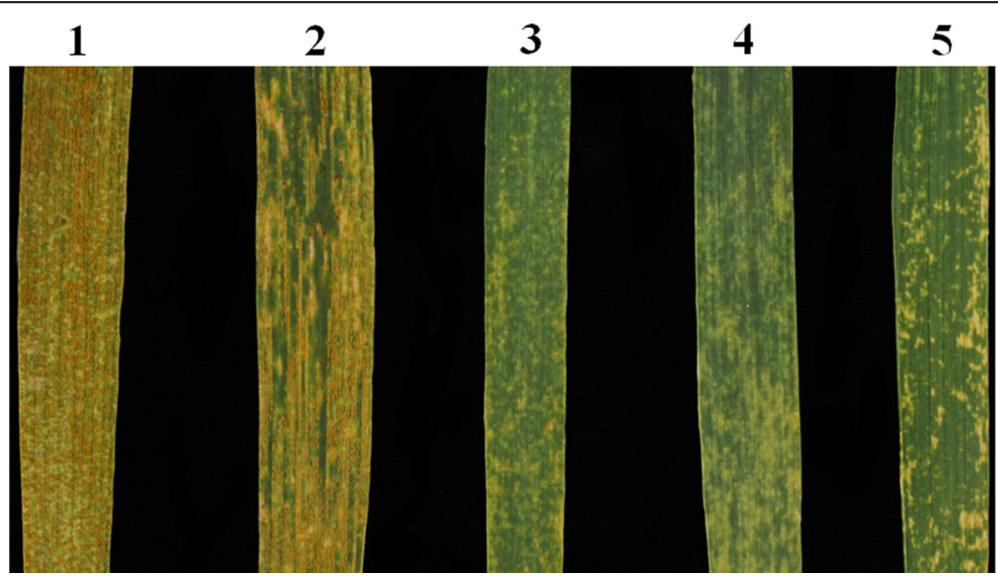

Fig. 7 Stripe rust resistance of K15-1192-2, K15-1194-2, and the controls at adult plant stages. 1, SY95-71; 2, CN16; 3, P1142-1-2; 4, K15-1194-2; 5, K15-1192-2 


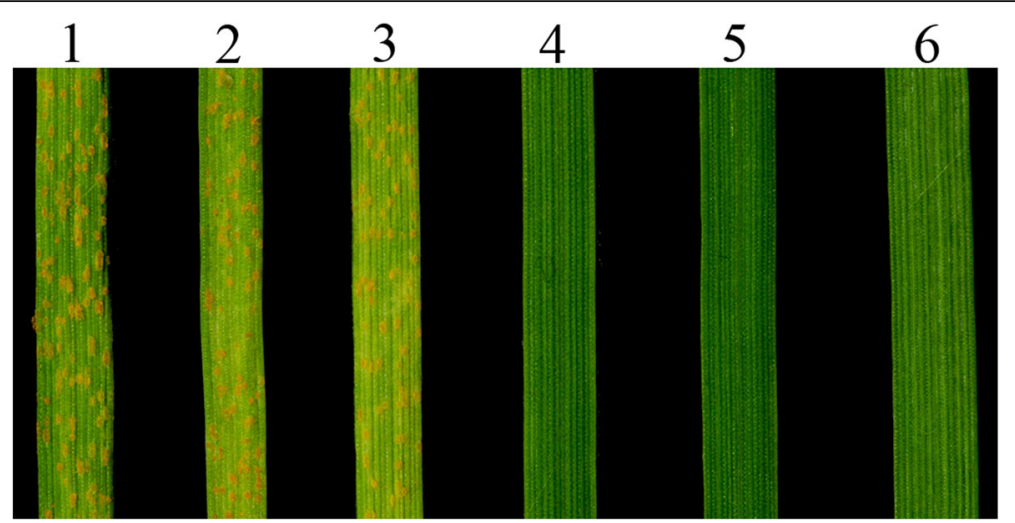

Fig. 8 Stripe rust resistance of K15-1192-2, K15-1194-2, and the controls at seedling stages. 1, SY95-71; 2, Crocus; 3, CN16; 4, P1142-1-2; 5, K15$1194-2 ; 6$, K15-1192-2

New stripe rust races CYR34 is effective against all the previously identified Pst races and has been deployed in commercial cultivars to fight predominant races of the fungus in China [15]. Very few genes are effective against CYR34, including $Y r 5,-15,-16,-18$, and the original sources of $\operatorname{Yr} 11,-12,-13$, and -14 [35]. This pathogen represents a serious threat to wheat production in the Sichuan Basin of China and potentially in other regions [15]. It is necessary to accelerate progress in identifying and utilizing new effective stripe rust resistance genes to develop new wheat varieties with durable resistance [16]. The wild relatives of wheat provided abundant and diverse resistance resources, such as $\operatorname{Yr} 15$, $-24 / 26,-35,-36,-53,-64$, and -65 from tetraploid wheat, $Y r 9$ from $S$. cereale, $Y r 8,-17,-28,-37,-38$, 40, $-42,-48$, and -70 from Aegilops species, and $\operatorname{Yr} 50$ from Th. intermedium [18]. In this study, K15-1192-2 and K15-1194-2, which were derived from P1142-1-2/ $2 * \mathrm{CN} 16 \mathrm{BC}_{1} \mathrm{~F}_{3}$ progenies, were highly resistant to prevalent Chinese Pst races at seedling and adult plant stages. The parent P1142-1-2 is resistant to all the tested races, while CN16 is susceptible. P1142-1-2 was derived from the cross 'Crocus'/E. repens//'Crocus' [21]. A survey of stripe rust resistance revealed that 'Crocus' was susceptible, and the resistance of P1142-1-2 was derived from E. repens. Therefore, this pedigree provides the only evidence that K15-1192-2 and K15-1194-2 carry the stripe rust resistance gene from 3St chromosome of E. repens. As far as we know, this is the first demonstration of a successful transfer of a new and high-level stripe rust resistance gene from $E$. repens that involves the St genome. The new wheat lines offer a novel resource for improving resistance to all the prevalent races of stripe rust present in the Sichuan Basin of China.

\section{Conclusions}

In conclusion, we developped and characterized two wheat $-E$. repens $3 \mathrm{St}$ chromosomal translocation lines by
GISH, FISH, SSR, and EST-SSR markers. Compared with the wheat parent, these translocation lines expressed high levels of resistance to FHB and stripe rust pathogens prevalent in China. Our study has determined that the chromosome 3St of E. repens harbors gene(s) highly resistant to FHB and stripe rust, and chromatin of 3St introgressed into wheat chromosomes completely presented the resistance, indicating the feasibility of using these translocation lines as novel material for breeding resistant wheat cultivars and alien gene mining.

\section{Methods}

\section{Plant materials}

The wheat $-E$. repens line P1142-1-2 $\quad(2 n=8 x=56)$, which has the characteristics of tolerance to cold, a variety of soil types, and heavy metals, as well as superior resistance to FHB and rust, was originally developed and identified from the crosses Crocus/E. repens//Crocus $\mathrm{BC}_{1} \mathrm{~F}_{9}$ progenies at the Eastern Cereal and Oilseed Research Center, Ottawa, Canada [21]. The native wheat cultivar Chuannong16 (CN16) is ideal recurrent parents for wheat breeding programs in southwestern China because it possesses a comprehensive array of good agronomical characteristics; however, it is susceptible to stripe rust, powdery mildew, and FHB [24]. To produce wheat $-E$. repens derivative line, we crossed P1142-1-2 with $\mathrm{CN} 16$, and the $\mathrm{F}_{1}$ was backcrossed with $\mathrm{CN} 16$. Then seeds selected from the $\mathrm{BC}_{1} \mathrm{~F}_{1}$ plants were bulked and advanced to the $\mathrm{BC}_{1} \mathrm{~F}_{3}$ generation by single seed descent. Two derivative lines K15-1192-2 and K151194-2, with high resistance to stripe rust and FHB over 2 years of observation, were isolated from the 76 P1142$1-2 / 2 * \mathrm{CN} 16 \mathrm{BC}_{1} \mathrm{~F}_{3}$ progeny lines (Fig. 9). Wheat line SY95-71 and Crocus was used as a susceptible control for diaease response tests. Wheat cultivar Chinese Spring (CS) was used as a positive control for the molecular marker analysis. Wheat cultivar J-11 was used as a source of blocking DNA, and E. repens accession 


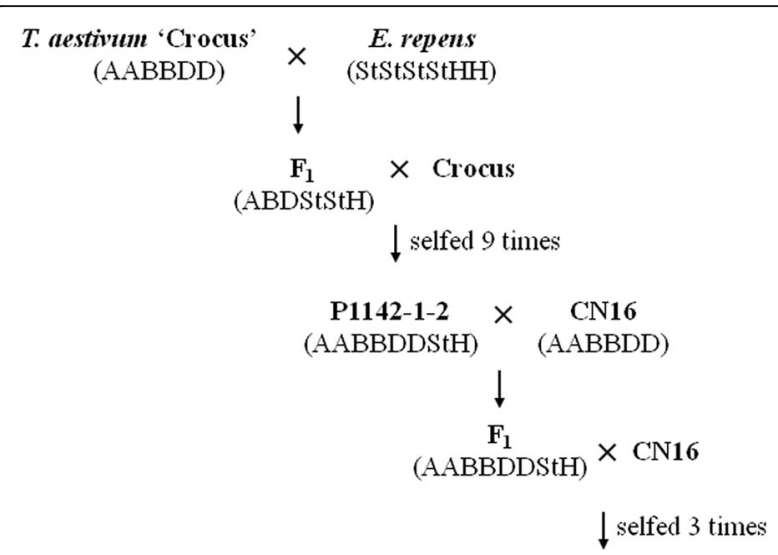

K15-1192-2; K15-1194-2

Fig. 9 Pedigree details of K15-1192-2 and K15-1194-2

PI229925, Hordeum bogdanii $(2 n=2 x=14$, HH) accession Y1819, and Pseudoroegneria strigosa accession W6$14049(2 n=2 x=14$, StSt $)$ were used as sources of probes DNA in GISH analysis. The voucher specimens have been deposited at herbarium of Triticeae Research Institute, Sichuan Agricultural University, China (SAUTI).

\section{Meiosis analysis}

The analysis of meiosis followed the procedures described by Kang et al. [36]. At least 50 pollen mother cells (PMCs) were observed for each plant. The images were captured with a DP-70 CCD camera using Olympus BX-63 microscope (Olympus, Tokyo, Japan).

\section{GISH and FISH analysis}

Root tips were treated and digested with the procedure of Komuro et al. [37], then the slides were prepared for GISH as described by Han et al. [38]. Genomic DNAs were extracted from fresh leaves of E. repens, H. bogdanii, Pse. strigosa, and wheat cultivar J-11 by the cetyltrimethylammonium bromide method [39]. E. repens, H. bogdanii, and Pse. strigosa DNAs were independently labeled with both fluorescein-12-dUTP (green) and Texas Red-12-dUTP (red) by the nick translation method (Thermo Fisher Scientific, Eugene, OR, USA), then used as the hybridization probes. GISH analysis was performed according to Han et al. [40] with a probe DNA to blocking agent DNA ratio of 1:150. Ten $\mu \mathrm{L}$ of hybridization solution containing $2 \times$ SSC (saline sodium citrate), $10 \%$ dextran sulphate, $10 \mathrm{ng} / \mu \mathrm{L}$ of labeled probe DNA together with blocking DNA were loaded per slide, denatured by heating at $85^{\circ} \mathrm{C}$ for 5 min, incubated for $8 \mathrm{~h}$ at $37^{\circ} \mathrm{C}$, and washed in $2 \times$ SSC at room temperature. Finally, the chromosomes were counterstained with 4,6-diamino-2-phenylindole solution (Vector Laboratories, Burlingame, CA, USA). The GISH images were captured with a DP-70 CCD camera using Olympus BX-63 microscope.

The GISH slides were washed with $70 \%(\mathrm{v} / \mathrm{v})$ ethanol for $5 \mathrm{~min}, 2 \times \mathrm{SSC}$ at $60^{\circ} \mathrm{C}$ for $30 \mathrm{~min}, \mathrm{ddH}_{2} \mathrm{O}$ (double distilled water) for $10 \mathrm{~min}$, and $100 \%(\mathrm{v} / \mathrm{v})$ ethanol for $5 \mathrm{~min}$, respectively. FISH analysis was subsequently used to identify the constitution of the lines K15-1192-2 and K151194-2, using pSc119.2 and pTa535 as probes [37, 41]. FISH was conducted according to Han et al. [38]. FISH signals were visualized under a fluorescence microscope (Olympus BX63), and images were captured by DP-70 CCD camera and analyzed by Adobe Photoshop software.

\section{Molecular marker analysis}

The specific Simple sequence repeat (SSR) primer pairs of the wheat D-genome chromosomes [42] were used to determine the wheat chromatin of K15-1192-2 and K15-1194-2. The expressed sequence tag-SSR (ESTSSR) primer pairs distributed in the seven homoeologous groups of wheat [22] were used to identify the alien chromatin in both lines. All the PCR primers were synthesized by TSINGKE (Chengdu, China), and the details are shown in Table 2. CS, P1142-1-2, and CN16 were used as controls. The PCR amplification were conducted as previously described $[22,42]$.

\section{Agronomical traits evaluation}

The seven morphological traits (including plant height, tiller number, spike length, spikelet per spike, grains per spike, thousand-grain weight, and seed setting rate) of K15-1192-2 and K15-1194-2 and their parents were evaluated in a field trial in Wenjiang, Sichuan Province, China with three replications. The detailed method was performed as described by Kang et al. [24]. Significant differences in traits were determined using the SAS 8.2 system (SAS Institute Inc., Cary, NC, USA).

\section{Evaluation of FHB resistance}

The plant inoculation experiments were performed according to Qi et al. [43]. At the mid-anthesis stage, two florets of a single central spikelet were point-inoculated with a $10-\mu \mathrm{L}$ solution with one thousand F. graminearum conidia in distilled water. The inoculated spikes were sprayed with water and wrapped in plastic film for $48 \mathrm{~h}$ to maintain humidity. The wheat plants were incubated at $25^{\circ} \mathrm{C}$ in a controlled-environment room. Head blight symptoms were assessed at 21 days after inoculation, with 5-10 plants per treatment.

\section{Stripe rust resistance screening}

K15-1192-2, K15-1194-2, P1142-1-2, CN16, and SY95-71 were evaluated for adult plant responses to a mixture of Pst 
Table 2 Sequences of wheat SSR and EST-SSR markers

\begin{tabular}{|c|c|c|c|c|c|}
\hline Marker & Primer sequence $\left(5^{\prime}-3^{\prime}\right)$ & Annealing temperature $\left({ }^{\circ} \mathrm{C}\right)$ & Arm location & ID of ESTs & References \\
\hline Xwmc14 & $\begin{array}{l}\text { F: ACCCGTCACCGGTTATGGATG } \\
\text { R: TCCACTTCAAGATGGAGGGCAG }\end{array}$ & 63 & 7DL(terminal) & - & Somers et al. 2004 \\
\hline Xbarc111 & $\begin{array}{l}\text { F: GCGGTCACCAGTAGTTCAACA } \\
\text { R: GCGTATCCCATTGCTCTTCTTCACTAAC }\end{array}$ & 60 & 7DL (proximal) & - & Somers et al. 2004 \\
\hline Xcfd211 & $\begin{array}{l}\text { F: AGAAGACTGCACGCAAGGAT } \\
\text { R: TGCACTAAAGCATCTTCGTGTT }\end{array}$ & 65 & 3DL (terminal) & - & Guyomarc'h et al. 2002 \\
\hline Xcfd64 & $\begin{array}{l}\text { F: ACAGTGTTGTTGCCCCTTTC } \\
\text { R: CCCATGTTACAGCTITGGGT }\end{array}$ & 64 & 3DS (terminal) & - & Guyomarc'h et al. 2002 \\
\hline 1EST-255 & $\begin{array}{l}\text { F: CCAGGACAGCCTATCCAAGA } \\
\text { R: TCGAAGTTGGACTTCAGCAA }\end{array}$ & 57 & $1 \mathrm{AL} 1 \mathrm{BL} 1 \mathrm{DL}$ & Ta\#S16058339 & Kong et al. 2018 \\
\hline 1EST-1134 & $\begin{array}{l}\text { F: CACAAACTATCCAAAGGATGA } \\
\text { R: GTGGAACATTTCAGGTGAC }\end{array}$ & 55 & 1AS 1DS & BG605065 & Kong et al. 2018 \\
\hline 2EST-983 & $\begin{array}{l}\text { F: ACAGGAGGTTGGATGAGTGG } \\
\text { R: TCCACGTGTGTITCGTCAAT }\end{array}$ & 57 & 2AS 2BS 2DS & BG314234 & Kong et al. 2018 \\
\hline 2EST-705 & $\begin{array}{l}\text { F: AGGTCACTGCAGGAGGAGGA } \\
\text { R: GAAAAGATGATGAGCTGGTCTGG }\end{array}$ & 55 & $2 \mathrm{BL} 2 \mathrm{DL}$ & BF293175 & Kong et al. 2018 \\
\hline 3EST-186 & $\begin{array}{l}\text { F: CAATTTGTTGCCTACGTCA } \\
\text { R: AGTTCTAATGGTGACCCACA }\end{array}$ & 55 & 3AL 3BL 3DL & BE406551 & Kong et al. 2018 \\
\hline 3EST-147 & $\begin{array}{l}\text { F: AAGCTCGTCTTCATCGTCTA } \\
\text { R: GTACAGCCCCAGCAGGTA }\end{array}$ & 55 & 3AS 3BS 3DS & BF293133 & Kong et al. 2018 \\
\hline 4EST-100 & $\begin{array}{l}\text { F: GTGCACTCCGTCGAAGCTA } \\
\text { R: AGGAGCTGGTGATGAACTGG }\end{array}$ & 58 & 4AS 4BL 4DL & BE497134 & Kong et al. 2018 \\
\hline 4EST-19 & $\begin{array}{l}\text { F: GTACGTAGCAGCCGATGGAT } \\
\text { R: CCCCGATCGAGAAGTTACAA }\end{array}$ & 57 & $4 \mathrm{AL} 4 \mathrm{DL}$ & BE637934 & Kong et al. 2018 \\
\hline 5EST-79 & $\begin{array}{l}\text { F: AAGTATGCAGCCAGATCTCA } \\
\text { R: GGTTATTGCTCTTGCAGATG }\end{array}$ & 54 & 5AL 5BL 5DL & BQ280540 & Kong et al. 2018 \\
\hline 5EST-10 & $\begin{array}{l}\text { F: GAGCTGGATCTTCAGCCTAT } \\
\text { R: AATTITGCCATGAGATCG }\end{array}$ & 53 & $5 \mathrm{AL}$ & BM137728 & Kong et al. 2018 \\
\hline 6EST-358 & $\begin{array}{l}\text { F: GTACCATTCGATTGTTCTGC } \\
\text { R: GGAAATCCTATGCCCTTAAT }\end{array}$ & 55 & 6AL 6BL 6DL & BE399146 & Kong et al. 2018 \\
\hline CINAU15 & $\begin{array}{l}\text { F: AGATCCAACACCAGTTCAAG } \\
\text { R: ATGTTATGGAGGCTTGTGTC }\end{array}$ & 53 & 6AS 6BS 6DS & Contig17515 & Kong et al. 2018 \\
\hline 7EST-133 & $\begin{array}{l}\text { F: CTCTTCCCCTCTCTCGTCCT } \\
\text { R: GCTCCAAATCTTCACCAAGC }\end{array}$ & 57 & 7DS & Ta\#S13057851 & Kong et al. 2018 \\
\hline 7EST-138 & $\begin{array}{l}\text { F: GATTAGGCAAATGGGTCA } \\
\text { R: CTCATCGGGTTCAGTGGT }\end{array}$ & 55 & 7AS 7BS 7DS & BE494425 & Kong et al. 2018 \\
\hline
\end{tabular}

$F$ forward primer; $R$ reverse primer

races (CYR-32, CYR-33, CYR-34, and V26/Gui22-14) in a field trial using the smear method [44] in the growing season 2017-2018 at Chengdu, Sichuan, China. The evaluation was conducted according to Kang et al. [24] with three replications. For each replication, 20 grains of each line were evenly planted in $2.0 \mathrm{~m}$ rows, spaced $0.3 \mathrm{~m}$ apart. K15-1192-2, K15-1194-2, P1142-1-2, CN16, Crocus, and SY95-71 were evaluated for seedling stage reacctions to Pst race (CYR-34) under growth chamber. The plants were inoculated and evaluated as described by Li et al. [45]. Wheat line SY95-71 was used as susceptible control. Stripe rust infection type (IT) was identified as described by Li et al. [45].

\section{Abbreviations}

CN16: Chuannong16; EST-SSR: Expressed sequence tag-simple sequence repeat; FHB: Fusarium head blight; FISH: Fluorescence in situ hybridization;
GISH: Genomic in situ hybridization; PCR: Polymerase chain reaction; PMCs: Pollen mother cells; Pst: Puccinia striiformis f. sp. tritici; SSRs: Simple sequence repeats

\section{Acknowledgments}

We thank Dr. George Fedak, Eastern Cereal and Oilseed Research Center, Ottawa, Canada, for kindly supplying P1142-1-2 material used in this study. We also thank Prof. QZ Jia, Plant Protection Institute of Gansu Academy of Agricultural Sciences, Gansu, China, for kindly supplying the urediniospores of the Pst races.

\section{Authors' contributions}

HYK and YHZ conceived and designed the study. BRG, WZ, SYL, YQW, LH, and PFQ conducted the experiments. XF, LNS, and HQZ analyzed the data. LLX, YW, and JZ interpreted the results and contributed to the preparation of the manuscript. BRG, GYC, and HYK drafted the work and substantively revised it. All authors read and approved the final manuscript. 


\section{Funding}

This work was funded by the National Natural Science Foundation of China (No. 31771781, 31971883), the National Key Research and Development Program of China (2016YFD0102000 and 2017YFD0100905), and the Science and Technology Bureau of Sichuan Province. The funding bodies were not involved in the design of the study, data collection, interpretation of data, or in writing the manuscript.

\section{Availability of data and materials}

The datasets generated and analyzed during the present study are available from the corresponding author on reasonable request.

\section{Ethics approval and consent to participate}

Not applicable.

\section{Consent for publication}

Not applicable.

\section{Competing interests}

The authors declare that they have no competing interests.

\section{Author details}

${ }^{1}$ State Key Laboratory of Crop Gene Exploration and Utilization in Southwest China, Sichuan Agricultural University, Chengdu 611130, Sichuan, China. ${ }^{2}$ Triticeae Research Institute, Sichuan Agricultural University, Chengdu 611130, Sichuan, China. ${ }^{3}$ College of Resources, Sichuan Agricultural University, Chengdu 611130, Sichuan, China.

Received: 16 July 2019 Accepted: 18 December 2019 Published online: 27 December 2019

\section{References}

1. Bai G, Shaner G. Management and resistance in wheat and barley to Fusarium head blight 1. Annu Rev Phytopathol. 2004;42:135-61.

2. Mansfield J, Genin S, Magori S, Citovsky V, Sriariyanum M, Ronald P, Dow M, Verdier V, Beer SV, Machado MA, Toth I, Salmond G, Foster GD. Top 10 plant pathogenic bacteria in molecular plant pathology. Mol Plant Pathol. 2012; 13:614-29.

3. Cetin Y, Bullerman LB. Cytotoxicity of Fusarium mycotoxins to mammalian cell cultures as determined by the MTT bioassay. Food Chem Toxicol. 2005; 43:755-64.

4. Pestka JJ. Deoxynivalenol: mechanisms of action, human exposure, and toxicological relevance. Arch Toxicol. 2010;84:663-79.

5. Su ZQ, Jin SJ, Zhang DD, Bai GH. Development and validation of diagnostic markers for Fhb1 region, a major QTL for Fusarium head blight resistance in wheat. Theor Appl Genet. 2018;131:2371-80.

6. Buerstmayr H, Ban T, Anderson JA. QTL mapping and markerassisted selection for Fusarium head blight resistance in wheat: a review. Plant Breed. 2009;128:1-26.

7. Zhang AM, Yang WL, Li X, Sun JZ. Current status and perspective on research against Fusarium head blight in wheat. Hereditas (Beijing). 2018;40: 858-73.

8. Qi LL, Pumphrey MQ, Friebe B, Chen PD, Gill BS. Molecular cytogenetic characterization of alien introgressions with gene Fhb3 for resistance to Fusarium head blight disease of wheat. Theor Appl Genet. 2008;117: 1155-66.

9. Cainong JC, Bockus WW, Feng Y, Chen P, Qi L, Sehgal SK, Danilova TV, Koo D-H, Friebe B, Gill BS. Chromosome engineering, mapping, and transferring of resistance to Fusarium head blight disease from Elymus tsukushiensis into wheat. Theor Appl Genet. 2015;128:1019-27.

10. Guo J, Zhang XL, Hou YL, Cai JJ, She XR, Zhou TT, Xu HH, Ohm WW, Wang HW, Li AF, Han FP, Wang HG, Kong LR. High-density mapping of the major FHB resistance gene Fhb7 derived from Thinopyrum ponticum and its pyramiding with Fhb1 by marker-assisted selection. Theor Appl Genet. 2015; 128:2301-16.

11. Wellings CR. Global status of stripe rust: a review of historical and current threats. Euphytica. 2011;179:129-41.

12. Chen XM. High-temperature adult-plant resistance, key for sustainable control of stripe rust. Am J Plant Sci. 2013;4:608.
13. Mclntosh RA, Dubcovsky J, Rogers WJ, Morris C, Xia XC. Catalogue of gene symbols for wheat: 2017 supplement. https://shigen.nig.ac.jp/wheat/ komugi/genes/macgene/supplement2017.pdf. Accessed 4 Aug 2018.

14. Gessese M, Bariana H, Wong D, Hayden M, Bansal U. Molecular mapping of stripe rust resistance gene Yr81 in a common wheat landrace Aus27430. Plant Dis. 2019. https://doi.org/10.1094/PDIS- 06-18-1055-RE.

15. Han DJ, Wang QL, Chen XM, Zeng QD, Wu JH, Xue WB, Zhang G, Huang L, Kang ZS. Emerging Yr26-virulent races of Puccinia striiformis f. tritici are threatening wheat production in the Sichuan Basin, China. Plant Dis. 2015; 99:754-60.

16. Ma J, Qin NN, Cai B, Chen GY, Ding PY, Zhang H, Yang CC, Huang L, Mu Y, Tang HP, Liu YX, Wang JR, Qi PF, Jiang QT, Zheng YL, Liu CJ, Lan XJ, Wei YM. Identification and validation of a novel major QTL for all-stage stripe rust resistance on 1BL in the winter wheat line 20828. Theor Appl Genet. 2019;132:1363-73.

17. Mullan DJ, Mirzaghaderi G, Walker E, Colmer TD, Francki MG. Development of wheat-Lophopyrum elongatum recombinant lines for enhanced sodium "exclusion" during salinity stress. Theor Appl Genet. 2009;119:1313-23.

18. Zheng SG, Li YF, Lu L, Liu ZH, Zhang CH, Ao DH, Li LR, Zhang CY, Liu R, Luo $C P, W u Y$, Lei Z. Evaluating the contribution of $Y r$ genes to stripe rust resistance breeding through marker-assisted detection in wheat. Euphytica. 2017;213:50.

19. Mahelka V, Kopecky D. Gene capture from across the grass family in the allohexaploid Eymus repens (L.) Gould (Poaceae, Triticeae) as evidenced by ITS, GBSSI, and molecular cytogenetics. Mol Biol Evol. 2010;27:1370-90.

20. Brej T. Heavy metal tolerance in Aropyron repens (L.) P. Bauv. Populations from the Legnica copper smelter area, lower Silesia. Acta Soc Bot Pol. 1998; 67:325-33.

21. Zeng J, Cao W, Hucl P, Yang Y, Xue AG, Chi D, Fedak G. Molecular cytogenetic analysis of wheat-Elymus repens introgression lines with resistance to Fusarium head blight. Genome. 2013;56:75-82.

22. Kong LN, Song XY, Xiao J, Sun HJ, Dai KL, Lan CX, Singh PW, Yuan CX, Zhang SZ, Singh R, Wang HY, Wang XE. Development and characterization of a complete set of Triticum aestivum-Roegneria ciliaris disomic addition lines. Theor Appl Genet. 2018;131:1793-806.

23. Falke KC, Sušić Z, Wilde P, Wortmann H, Möhring J, Piepho HP, Geiger HH, Miedaner T. Testcross performance of rye introgression lines developed by marker-assisted backcrossing using an Iranian accession as donor. Theor Appl Genet. 2009;118:1225-38

24. Kang HY, Zhang ZJ, Xu LL, Qi WL, Tang Y, Wang H, Zhu W, Li DY, Zeng J, Wang Y, Fan X, Sha LN, Zhang HQ, Zhou YH. Characterization of wheat - Psathyrostachys huashanica small segment translocation line with enhanced kernels per spike and stripe rust resistance. Genome. 2016;59:221-9.

25. Cseh A, Yang CY, Hubbart-Edwards S, Scholefield D, Ashling SS, Burridge AJ, Wilkinson PA, King IP, King J, Grewal S. Development and validation of an exome-based SNP marker set for identification of the St, $J^{r}$ and $J^{v s}$ genomes of Thinopyrym intermedium in a wheat background. Theor Appl Genet. 2019; 132:1555-70.

26. Jiang J, Chen PD, Friebe B, Raupp WJ, Gill BS. Alloplasmic wheat-Elymus ciliaris chromosome addition lines. Genome. 1993:36:327-33.

27. Jiang J, Morris KLD, Gill BS. Introgression of Elymus trachaycaulus chromatin into common wheat. Chromosom Res. 1994;2:3-13.

28. Wang SL, Qi LL, Chen PD, Liu DJ, Friebe B, Gill BS. Molecular cytogenetic identification of wheat-Elymus tsukushiense introgression lines. Euphytica. 1999;107:217-24.

29. Fedak G, Comeau A, St-Pierre CA. Meiosis in Triticum aestivum $\times$ Elytrigia repens hybrids. Genome. 1986;28:430-2.

30. Fedak G, Cao WG, Wolfe D, Chi D, Xue A. Molecular characterization of Fusarium resistance from Elymus repens introgressed into bread wheat. Cytol Genet. 2017;51:130-3.

31. Brisco El, Brown LK, Olson EL. Fusarium head blight resistance in Aegilops tauschii. Genet Resour Cro Evol. 2017;64:2049-58.

32. Liu DJ, Weng YQ, Chen PD. Transfer of scab resistance from Roegneria C. Koch (Agropyron) species into wheat. In proceedings of the 2nd international symposium on chromosome engineering in plants. G Kimber. University of Missouri, Columbia, Mo. 1990. p. 166-176.

33. Fu S, Lv Z, Qi B, Guo X, Li J, Liu B, Han F. Molecular cytogenetic characterization of wheat-Thinopyrum elongatum addition, substitution and translocation lines with a novel source of resistance to wheat Fusarium head blight. J Genet Genomics. 2012;39:103-10. 
34. McArthur Rl, Zhu X, Oliver RE, Klindworth DL, Xu SS, Stack RW, Wang RR, Cai $X$. Homoeology of Thinopyrum junceum and Elymus rectisetus chromosomes to wheat and disease resistance conferred by the Thinopyrum and Elymus chromosomes in wheat. Chromosom Res. 2012;20:699-715

35. Wu J, Wang Q, Xu L, Chen X, Li B, Mu J, Zeng Q, Huang L, Han D, Kang Z. Combining single nucleotide polymorphism genotyping array with bulked segregant analysis to map a gene controlling adult plant resistance to stripe rust in wheat line 03031-1-5H62. Phytopathology. 2017;108:103-13.

36. Kang HY, Huang J, Zhu W, Li DY, Diao CD, Tang L, Wang Y, Xu LL, Zeng J, Fan X, Sha LN, Zhang HQ, Zheng YL, Zhou YH. Cytogenetic behavior of trigeneric hybrid progeny involving wheat, rye and Psathyrostachys huashanica. Cytogenet Genome Res. 2016;148:74-82.

37. Komuro S, Endo R, Shikata K, Kato A. Genomic and chromosomal distribution patterns of various repeated DNA sequences in wheat revealed by a fluorescence in situ hybridization procedure. Genome. 2013;56:131-7.

38. Han F, Lamb J, Birchler J. High frequency of centromere inactivation resulting in stable dicentric chromosomes of maize. Proc Natl Acad Sci U S A. 2006;103:3238-43.

39. Allen GC, Flores-Vergara MA, Krasynanski S, Kumar S, Thompson WF. A modified protocol for rapid DNA isolation from plant tissues using cetyltrimethylammonium bromide. Nat Protoc. 2006;1:2320-5.

40. Han F, Gao Z, Birchler JA. Reactivation of an inactive centromere reveals epigenetic and structural components for centromere specification in maize. Plant Cell. 2009;21:1929-39.

41. McIntyre C, Pereira S, Moran L, Appels R. New Secale cereale (rye) DNA derivatives for the detection of rye chromosome segments in wheat Genome. 1990;33:635-40.

42. Somers DJ, Isaac P, Edwards K. A high-density microsatellite consensus map for common wheat (Triticum aestivum L.). Theor Appl Genet. 2004;109:1105-14.

43. Qi PF, Zhang YZ, Liu CH, Chen Q, Guo ZR, Wang Y, Xu BJ, Jiang YF, Zheng T, Gong X, Luo CH, Wu W, Kong L, Deng M, Ma J, Lan XJ, Jiang QT, Wei YM, Wang JR, Zheng YL. Functional analysis of FgNahG clarifies the contribution of salicylic acid to wheat (Triticum aestivum) resistance against Fusarium head blight. Toxins. 2019;11:59.

44. Carter AH, Chen XM, Garland-Campbell K, Kidwell KK. Identifying QTL for high-temperature adult-plant resistance to stripe rust (Puccinia striiformis $\mathrm{f}$. sp. tritici) in the spring wheat (Triticum aestivum L.) cultivar 'Louise'. Theor Appl Genet. 2009;119:1119-28.

45. Li DY, Zhang JW, Liu HJ, Tan BW, Zhu W, Xu LL, Wang Y, Zeng J, Fan X, Sha LN, Zhang HQ, Ma J, Chen GY, Zhou YH, Kang HY. Characterization of a wheat-tetraploid Thinopyrum elongatum 1E(1D) substitution line K17-841-1 by cytological and phenotypic analysis and developed molecular markers. BMC Genomics. 2019;20:963.

\section{Publisher's Note}

Springer Nature remains neutral with regard to jurisdictional claims in published maps and institutional affiliations.

Ready to submit your research? Choose BMC and benefit from:

- fast, convenient online submission

- thorough peer review by experienced researchers in your field

- rapid publication on acceptance

- support for research data, including large and complex data types

- gold Open Access which fosters wider collaboration and increased citations

- maximum visibility for your research: over $100 \mathrm{M}$ website views per year

At $\mathrm{BMC}$, research is always in progress.

Learn more biomedcentral.com/submissions 